\title{
Temporal transcription map of the Lactococcus lactis bacteriophage sk 1
}

\author{
P. Scott Chandry, ${ }^{1}$ Barrie E. Davidson ${ }^{2}$ and Alan J. Hillier ${ }^{1}$ \\ Author for correspondence: Alan J. Hillier. Tel: +613344 5915. Fax: +6133477730. \\ e-mail : Alan $=$ Hillier\%Biochem\%UNIMELB $@$ muwaye.unimelb.EDU.AU
}

1 Commonwealth Scientific and Industrial Research Organization, Division of Food Science and

Technology, Dairy Research Laboratory, PO Box 20, Highett, Victoria 3190, Australia

2 Russell Grimwade School of Biochemistry, University of Melbourne, Parkville, Victoria 3052, Australia

\begin{abstract}
Bacteriophage sk1 is a small isometric-headed lytic phage that infects Lactococcus lactis. The phage has a linear double-stranded DNA genome of 28 kbp, with cohesive ends. RNA was prepared from phage-infected $L$. lactis cells harvested at various intervals after infection, and the RNA molecules were resolved by electrophoresis. Northern blots of these gels were hybridized with sk1 DNA probes and the results obtained from these experiments, together with the results of primer extension analyses, enabled a transcription map of the phage genome to be prepared. Three classes of phage transcripts, designated as early, middle or late based on their time of appearance, were detected. Seven partially overlapping early transcripts were detected; these were transcribed from a $10 \mathrm{kbp}$ region of the phage. The nine middle transcripts were derived from a 2 kbp region, limited by cos at one end and the start of the early transcripts at the other. The early and middle transcripts were transcribed divergently from a region mapping at $26 \mathrm{kbp}$ on the sk1 physical map. The four late transcripts were derived from a $16 \mathrm{kbp}$ region of the phage limited at one end by cos. The late transcripts were transcribed in the opposite direction to the early transcripts and three of the late transcripts terminated in the same region of the phage genome as three of the early transcripts.
\end{abstract}

Keywords: small isometric-headed bacteriophage sk1, Lactococcus lactis, transcription map

\section{INTRODUCTION}

Bacteria belonging to the genus Lactococcus are used extensively in the fermentation of dairy products to convert lactose to lactic acid. The fermentation is carried out in a non-sterile environment and the starter bacteria are susceptible to infection by bacteriophages. This phage infection of starter bacteria is still the major cause of slow acid production in cheese manufacture and there is currently considerable interest in using genetic procedures to enhance the phage resistance properties of starter bacteria (Klaenhammer, 1987; Powell et al., 1990; Ward et al., 1992; O'Sullivan et al., 1993). Lactococcal phages have been differentiated into 12 species on the basis of their morphology and DNA homology (Jarvis et al., 1991). The phages isolated from cheese factories are of two major morphological types (Terzaghi, 1976): small isometric-headed phages (Siphoviridae, morphotype B1) and prolate-headed phages (Siphoviridae, morphotype B2). These two types represent $84 \%$ and $13 \%$ respectively of the phage isolated from New Zealand cheese factories (Terzaghi, 1976). Despite the considerable economic significance of phage infection of cheese starter bacteria, there is little information at the molecular level about the life cycle of these phages or their interaction with their host. Lactococcal phage genes that have been cloned and sequenced include genes encoding some of the structural proteins of the small isometric-headed phage F4-1 (Kim \& Batt, 1991; Chung et al., 1991), the lysin genes from $\phi v M L 3$, c2 and $\phi$ US3 (Shearman et al., 1989; Platteeuw \& de Vos, 1992; Ward et al., 1993), and a type II methyltransferase (Hill et al., 1991). In addition, a putative regulator gene bpi (Lakshmidevi et al., 1991) and the int gene (Lillehaug \& Birkeland, 1993) from temperate lactococcal phages have been cloned and sequenced.

The lactococcal phage sk1 has been shown to have a double-stranded DNA genome, $28 \mathrm{kbp}$ in length (Pillidge \& Jarvis, 1988; Powell et al., 1989), the nucleotide sequence of its cohesive ends has been determined (Chandry et al., 1994) and a low-resolution transcript map of the phage has been determined (Beresford et al., 1993). This paper describes the construction of a detailed transcript map for the small isometric-headed lactococcal phage sk 1 . 
Table 1. DNA probes used to map sk1 transcripts

\begin{tabular}{|c|c|c|}
\hline $\begin{array}{l}\text { DNA } \\
\text { probe* }\end{array}$ & $\begin{array}{l}\text { Map } \\
\text { position } †\end{array}$ & Comments $\ddagger$ \\
\hline EvB & $20 \cdot 5-26 \cdot 3$ & Fragment cloned in pJDC9 \\
\hline $\mathrm{EvC}$ & $15 \cdot 7-20 \cdot 4$ & Fragment cloned in pJDC9 \\
\hline EvF & $26 \cdot 7-28 \cdot 0$ & Fragment cloned in pJDC9 \\
\hline $\mathrm{EvG}$ & $26 \cdot 3-26 \cdot 7$ & Fragment cloned in pJDC9 \\
\hline $\mathrm{HiC}$ & $22 \cdot 1-24 \cdot 5$ & Fragment cloned in pJDC9 \\
\hline $\mathrm{HiC}-21$ & $23 \cdot 6-24 \cdot 5$ & $\begin{array}{l}\text { HiC deleted by } 1.5 \mathrm{kbp} \text { from left end by treatment with } \\
\text { exonuclease III and cloned in pJDC9 }\end{array}$ \\
\hline $\mathrm{HiC}-24$ & $22 \cdot 6-24 \cdot 5$ & $\begin{array}{l}\text { HiC deleted by } 0.5 \mathrm{kbp} \text { from left end by treatment with } \\
\text { exonuclease III and cloned in pJDC9 }\end{array}$ \\
\hline $\mathrm{HiC}-36$ & $23 \cdot 9-24 \cdot 5$ & $\begin{array}{l}\text { HiC deleted by } 1.8 \mathrm{kbp} \text { from left end by treatment with } \\
\text { exonuclease III and cloned in pJDC9 }\end{array}$ \\
\hline HiD & $24 \cdot 5-26 \cdot 6$ & Gel purified from HindIIl digest of $\mathrm{sk} 1$ \\
\hline $\mathrm{MsD}$ & $15 \cdot 0-16 \cdot 2$ & Fragment cloned in pJDC9 \\
\hline PvB & $9 \cdot 5-14 \cdot 6$ & Fragment cloned in pJDC9 \\
\hline PvD & $6 \cdot 9-9 \cdot 5$ & Fragment cloned in pJDC? \\
\hline PvE & $5 \cdot 1-6 \cdot 9$ & Fragment cloned in pJDC9 \\
\hline $\mathrm{Sa} \Delta \mathrm{A} 2$ & $19 \cdot 8-22 \cdot 3$ & Spontaneous deletion of SaA2 cloned into pJDC9 \\
\hline $\mathrm{Sa} \Delta \mathrm{A} 2-39$ & $21 \cdot 3-22 \cdot 3$ & $\begin{array}{l}\text { Sa } \triangle \mathrm{A} 2 \text { deleted by } 1.5 \mathrm{kbp} \text { from left end by treatment with } \\
\text { exonuclease III and cloned into pJDC9 }\end{array}$ \\
\hline SaE1 & $14 \cdot 2-15 \cdot 7$ & Fragment cloned in pJDC9 \\
\hline $\mathrm{SaG}$ & $15 \cdot 8-16 \cdot 5$ & Fragment cloned in pJDC9 \\
\hline $\mathrm{SsC}$ & $12 \cdot 1-16 \cdot 2$ & Fragment cloned in pJDC9 \\
\hline $\mathrm{S} s \mathrm{C}-6$ & $12 \cdot 1-15 \cdot 8$ & $\begin{array}{l}\text { SsC deleted by } 400 \text { bp from right end by treatment with } \\
\text { exonuclease III and cloned in pJDC9 }\end{array}$ \\
\hline $\mathrm{SsC}-44$ & $12 \cdot 1-16 \cdot 0$ & $\begin{array}{l}\text { SsC deleted by } 200 \text { bp from right end by treatment with } \\
\text { exonuclease III and cloned in pJDC9 }\end{array}$ \\
\hline Ss $j$ & $16 \cdot 2-16 \cdot 6$ & Fragment cloned in PJDC 9 \\
\hline SsLNPR & $24 \cdot 5-26 \cdot 0$ & $\begin{array}{l}\text { Product of partial } S_{s p \text { I digestion of sk1 DNA cloned into }} \\
\text { pJDC9 }\end{array}$ \\
\hline SsLNPR-23 & $25 \cdot 6-26 \cdot 0$ & $\begin{array}{l}\text { SsLNPR deleted by } 1 \cdot 1 \mathrm{kbp} \text { from left end by treatment with } \\
\text { exonuclease III and cloned into pJDC9 }\end{array}$ \\
\hline SsLNPR-28 & $25 \cdot 8-26 \cdot 0$ & $\begin{array}{l}\text { SsLNPR deleted by } 1.3 \mathrm{kbp} \text { from left end by treatment with } \\
\text { exonuclease III and cloned into pJDC9 }\end{array}$ \\
\hline SsLNPR-33 & $25 \cdot 7-26 \cdot 0$ & $\begin{array}{l}\text { SsLNPR deleted by } 1.2 \mathrm{kbp} \text { from left end by treatment with } \\
\text { exonuclease III and cloned into pJDC9 }\end{array}$ \\
\hline SsNPR & $25 \cdot 1-26 \cdot 0$ & $\begin{array}{l}\text { Product of partial } S_{s p I} \text { digestion of sk1 DNA cloned into } \\
\text { pJDC9 }\end{array}$ \\
\hline SsNPR-10 & $25 \cdot 1-25 \cdot 3$ & $\begin{array}{l}\text { SsNPR deleted by } 0.7 \mathrm{kbp} \text { from right end by treatment with } \\
\text { exonuclease III and cloned into pJDC } 9\end{array}$ \\
\hline
\end{tabular}

* sk1 restriction fragment as described in Fig. 1. Hyphenated numbers indicate restriction fragments that were truncated by treatment with exonuclease III prior to cloning.

† As shown in Fig. 1.

$\ddagger$ Entire plasmid was used as DNA probe unless otherwise indicated.

\section{METHODS}

Bacterial growth conditions. Lactococcus lactis subsp. lactis strain HID113 (Powell et al., 1990) was grown at $30^{\circ} \mathrm{C}$ in M17 medium (Terzaghi \& Sandine, 1975) containing 0.5\% (w/v) glucose (M17G).

Preparation of phage. Overnight cultures of HID113 were diluted $1: 100$ into fresh $\mathrm{M} 17 \mathrm{G}$ containing $10 \mathrm{~m} \mathrm{M} \mathrm{CaCl}_{2}$ and sk1 phage was added to a final titre of $5 \times 10^{4}$ p.f.u. $\mathrm{ml}^{-1}$. After incubation at $30^{\circ} \mathrm{C}$ for $16 \mathrm{~h}$, the lysates, containing $5 \times 10^{9}$ to $1 \times 10^{10}$ p.f.u. $\mathrm{ml}^{-1}$, were clarified by centrifugation at $13000 \mathrm{~g}$ for 15 min, adjusted to $\mathrm{pH} 7 \cdot 0$ with $2 \mathrm{M}$ Tris $/ \mathrm{HCl}(\mathrm{pH} \mathrm{7.0)}$ and filtered through a $0.45 \mu \mathrm{m}$ filter. DNA was isolated from the phage particles essentially by the procedure described for the isolation of $\lambda$ DNA in the Qiagenologist (Qiagen, Chatsworth, CA, USA) except that the volume of lysate was eightfold greater than that recommended for phage $\lambda$ and the phage were incubated with proteinase $\mathrm{K}\left(50 \mu \mathrm{g} \mathrm{m} \mathrm{m}^{-1}\right)$ at $65^{\circ} \mathrm{C}$ for $10 \mathrm{~min}$, prior to the addition of SDS.

Isolation of lactococcal RNA. Lactococcal RNA was prepared using a modification of the acid phenol extraction method of 


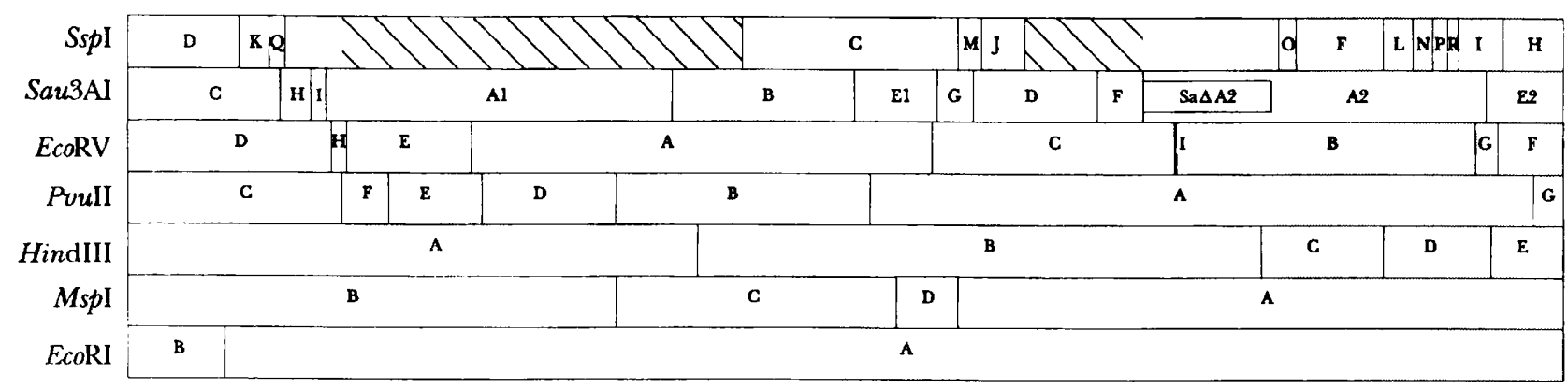

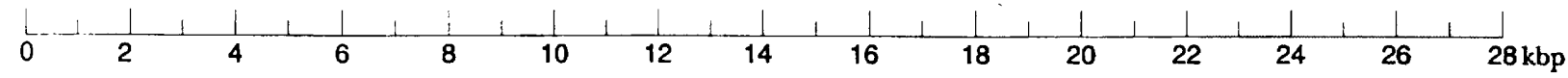

Fig. 1. Restriction map of sk1 DNA. Complete restriction maps for the enzymes EcoRI, EcoRV, HindlII, Pvull, Sau3Al and Mspl, and an incomplete map for Sspl, are shown. The nomenclature for restriction fragments combines the first two letters of the restriction enzyme (except for EcoRV, which is called Ev to avoid confusion with EcoRI) with the letters A, B, etc., in order of decreasing fragment size. Fragments of the same size are assigned the same letter with a number appended to each (e.g. A1, A2, etc.). Regions where restriction sites have not been determined for Sspl are hatched. The box marked $\mathrm{Sa} \triangle \mathrm{A} 2$ shows the location of a cloned Sau3Al subfragment which presumably resulted from the spontaneous deletion of the right end of SaA2.

van Rooijen \& de Vos (1990). L. lactis HID113 was grown to an $\mathrm{OD}_{660}$ of 0.3 in $\mathrm{M} 17 \mathrm{G}$, then $\mathrm{CaCl}_{2}$ was added to a final concentration of $10 \mathrm{mM}$. Immediately prior to infection with $\mathrm{sk} 1$, a $30 \mathrm{ml}$ sample of the culture was transferred into a $125 \mathrm{ml}$ flask containing $9 \mathrm{ml}$ ice-cold buffer A $(20 \mathrm{mM}$ Tris $/ \mathrm{HCl}$ $\mathrm{pH} 7.5,20 \mathrm{mM}$ sodium azide, $400 \mu \mathrm{g}$ chloramphenicol ml $\mathrm{ml}^{-1}$ ) and quickly chilled by swirling in an ice/ethanol bath. The remaining cells were infected with sk1 at a multiplicity of infection (m.o.i.) of approximately 5. Aliquots $(30 \mathrm{ml})$ of the infected cells, taken immediately after phage addition (time $=0$ ) and at the times indicated in individual experiments, were treated as described for the uninfected sample. The chilled cells suspended in buffer $A$ were harvested by centrifugation, washed once with buffer $A$ and resuspended in $1 \mathrm{ml}$ buffer $B(25 \%, w / v$, sucrose, $50 \mathrm{mM}$ Tris $/ \mathrm{HCl} \mathrm{pH} 7 \cdot 5,1 \mathrm{mM}$ EDTA). After the addition of lysozyme to a final concentration of $1.5 \mu \mathrm{g} \mathrm{ml}^{-1}$, and incubation of the mixture on ice for $10 \mathrm{~min}$, the cells were harvested by centrifugation and quickly resuspended in $350 \mu \mathrm{l}$ buffer $\mathrm{C}(20 \mathrm{mM}$ sodium acetate $\mathrm{pH} 5.2,3 \mathrm{mM}$ EDTA, $150 \mathrm{mM}$ $\mathrm{NaCl}$ ) at $0{ }^{\circ} \mathrm{C}$. An equal volume of buffer $\mathrm{C}$ containing $2 \%$ (w/v) SDS and preheated to $95{ }^{\circ} \mathrm{C}$ was added and the mixture was incubated at $95^{\circ} \mathrm{C}$ for $1 \mathrm{~min}$. The lysed cells were extracted with an equal volume of a $1: 1$ mixture of acid phenol (equilibrated with $20 \mathrm{mM}$ sodium acetate, $\mathrm{pH} 5 \cdot 2$ ) and chloroform (chloroform: isoamyl alcohol, $24: 1, \mathrm{v} / \mathrm{v}$ ) at $55^{\circ} \mathrm{C}$ for $1 \mathrm{~min}$. The aqueous phase was extracted a further four times with acid phenol/chloroform at room temperature, once with chloroform/isoamyl alcohol $(24: 1)$ and the RNA was precipitated with 2-propanol. The RNA samples were dissolved in $50 \mu \mathrm{l}$ water and incubated with $35 \mathrm{U}$ of RNase-free DNase I to remove any contaminating DNA.

Northern blots and hybridizations. RNA was analysed by electrophoresis through $1 \%(\mathrm{w} / \mathrm{v})$ agarose gels containing $2.2 \mathrm{M}$ formaldehyde (Maniatis et al., 1982). After electrophoresis, gels were washed several times with water then stained brietly with ethidium bromide to visualize the ribosomal RNA bands and RNA size markers $(0 \cdot 24-9 \cdot 5 \mathrm{~kb}$, Bethesda Research Labs). Transfer to Hybond $\mathrm{N}+$ membranes (Amersham) was carried out by capillary transfer as recommended by the membrane manufacturer. Hybridizations were carried out at $65^{\circ} \mathrm{C}$ for $12 \mathrm{~h}$ in a solution containing $5 \times$ SSPE $[1 \times$ SSPE is $150 \mathrm{mM} \mathrm{NaCl}, 9 \cdot 7 \mathrm{mM}$ sodium phosphate, and $1 \mathrm{mM}$ EDTA ( $\mathrm{pH} 7 \cdot 4)$ (Maniatis et al., 1982)], $5 \times$ Denhardt's solution (Maniatis et al., 1982) and $0.5 \%(\mathrm{w} / \mathrm{v})$ SDS. Final washing of the membrane was with $1 \times \operatorname{SSPE}, 0.1 \%(\mathrm{w} / \mathrm{v}) \operatorname{SDS}$ at $65^{\circ} \mathrm{C}$ for $15 \mathrm{~min} .{ }^{32} \mathrm{P}$-labelled DNA probes were prepared by the random primer procedure (Feinberg \& Vogelstein, 1984) using gel-purified phage restriction fragments or cloned phage fragments (Table 1).

Preparation of single-stranded DNA probes. The sk1 DNA fragment Sa $\triangle \mathrm{A} 2$ (Table 1, Fig. 1) cloned in pJDC9 (Chen \& Morrison, 1988) was used as template for single-stranded probe generation. M13 universal primer or M13 reverse primer $(1 \mu \mathrm{M})$ was mixed with 50 ng template DNA. Thermal cycling reactions were performed with $1 \mathrm{U}$ Taq DNA polymerase (Boehringer Mannheim), in a reaction mixture containing $50 \mu \mathrm{M} \mathrm{dCTP,}$ $50 \mu \mathrm{M} \quad \mathrm{dGTP}, 50 \mu \mathrm{M}$ dTTP, $1.6 \mu \mathrm{M}$ dATP, $2.5 \mu \mathrm{Ci}[\alpha-$ ${ }^{32} \mathrm{P}$ dATP, $10 \mathrm{mM}$ Tris/ $\mathrm{HCl} \mathrm{pH} \mathrm{8.3,1.5} \mathrm{mM} \mathrm{MgCl}, 50 \mathrm{mM}$ $\mathrm{KCl}$, and $0.1 \mathrm{mg}$ gelatin $\mathrm{ml}^{-1}$. The reactions were cycled 30 times at $94{ }^{\circ} \mathrm{C}$ for $1.5 \mathrm{~min}, 50^{\circ} \mathrm{C}$ for $2 \mathrm{~min}$, and $72{ }^{\circ} \mathrm{C}$ for $5 \mathrm{~min}$.

Primer extension analysis. Total RNA was isolated from sk1infected cells as described above. Oligonucleotide primers were synthesized on an Applied Biosystems model 381A DNA synthesizer and approximately $0.25 \mu \mathrm{g}$ annealed with $15 \mu \mathrm{g}$ RNA in $3 \mu \mathrm{l}$ water by incubating at $90^{\circ} \mathrm{C}$ for $1 \mathrm{~min}$ and then at $42{ }^{\circ} \mathrm{C}$ for $5 \mathrm{~min}$. Radiolabelled $\mathrm{cDNA}$ was synthesized in $10 \mu \mathrm{l}$ total volume reactions containing the RNA/primer mixture, $24 \mathrm{U}$ AMV reverse transcriptase, $15 \mu \mathrm{Ci}\left[\alpha^{3}{ }^{32} \mathrm{P}\right] \mathrm{dATP}, 100 \mu \mathrm{M}$ dCTP, $100 \mu \mathrm{M}$ dGTP, $100 \mu \mathrm{M}$ dTTP, $10 \mu \mathrm{M}$ dATP, $50 \mathrm{mM}$ Tris $/ \mathrm{HCl} \mathrm{pH} 8.5,50 \mathrm{mM} \mathrm{KCl}, 20 \mathrm{mM} \mathrm{MgCl}_{2}$, and $10 \mathrm{mM}$ DTT. Reactions were incubated at $42{ }^{\circ} \mathrm{C}$ for $30 \mathrm{~min}$ then stopped by the addition of $5 \mu 195 \%$ formamide, $20 \mathrm{mM}$ EDTA, $0.05 \%$ bromophenol blue and $0.05 \%$ xylene cyanol. The products were analysed, along with DNA sequencing ladders, on $6 \%(\mathrm{w} / \mathrm{v})$ polyacrylamide gels containing $7 \mathrm{M}$ urea and detected by autoradiography. Cloned sk 1 DNA fragments were used as template for sequencing with the Sequenase kit utilizing the same primers used to determine the $5^{\prime}$ ends of the RNA. 
(a)

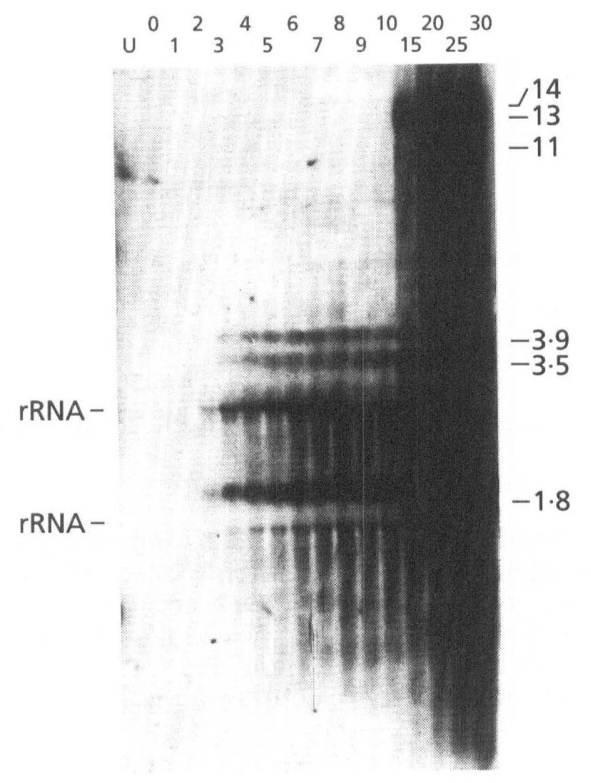

(c)

$$
U^{0} 1^{2} 3^{4} 5^{6} 7^{8} 9^{10}{ }_{15}^{20} 25^{30}
$$

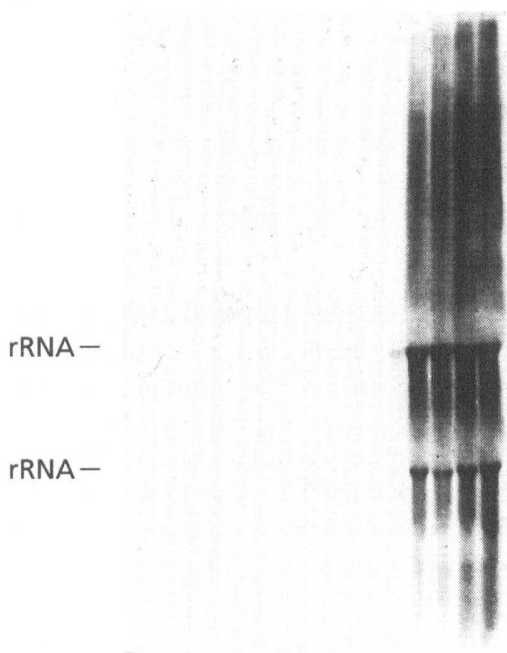

(b)

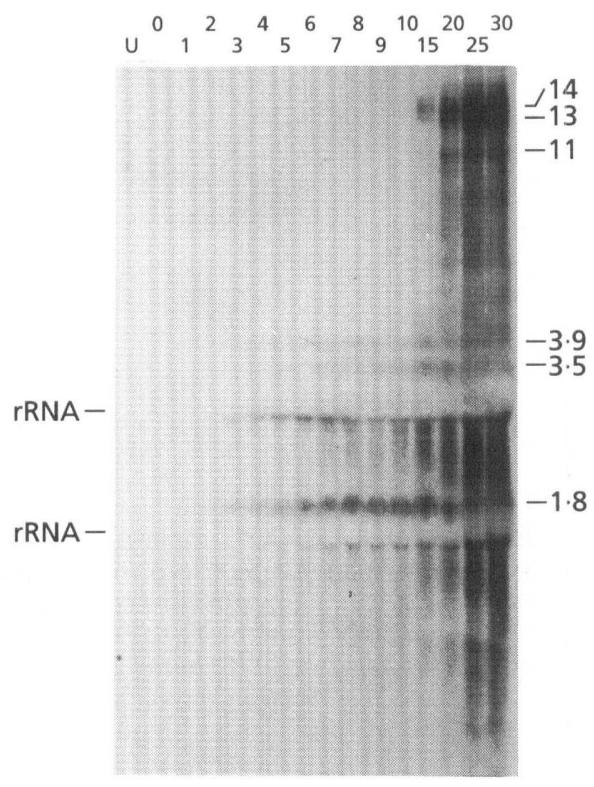

(d)

$$
U^{0}{ }_{1}{ }^{2} 3^{4} 5^{6} 7^{8} 9^{10}{ }_{15}^{20} 25^{30}
$$

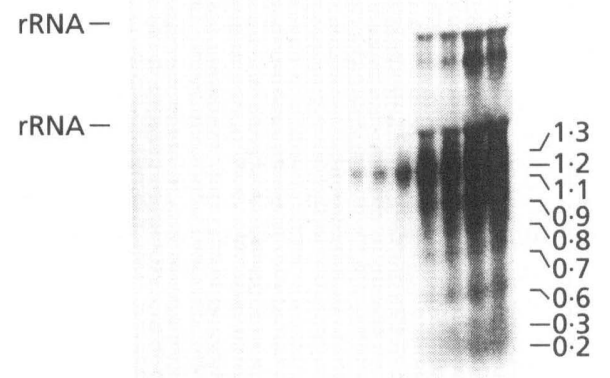

Fig. 2 (continued on facing page). Northern blots of RNA from sk1-infected L. lactis, hybridized with: (a), MsD (autoradiograph exposed for $5 \mathrm{~d}$ ); (b), MsD (autoradiograph exposed for $16 \mathrm{~h}$ ); (c), EvD; (d), EvF; (e), SsC; (f), EvB; and (g), $\mathrm{Sa} \triangle \mathrm{A}$ 2. One blot was used for panels (a-d), a second was used for panels $(e)$ and $(\mathrm{g})$, and a third was used for panel (f). RNA was prepared from uninfected cells immediately prior to infection (lane U), immediately after infection (lane 0), and at the following times post-infection: $1 \mathrm{~min}$ (lane 1), $2 \mathrm{~min}$ (lane 2), $3 \mathrm{~min}$ (lane 3), $4 \mathrm{~min}$ (lane 4), $5 \mathrm{~min}$ (lane 5), $6 \mathrm{~min}$ (lane 6), $7 \mathrm{~min}$ (lane 7), $8 \mathrm{~min}$ (lane 8), $9 \mathrm{~min}$ (lane 9), $10 \mathrm{~min}$ (lane 10), $15 \mathrm{~min}$ (lane 15), $20 \mathrm{~min}$ (lane 20), $25 \mathrm{~min}$ (lane 25), and $30 \mathrm{~min}$ (lane 30). Bands marked rRNA designate regions of nonspecific hybridization at the front of the 23S and $16 \mathrm{~S}$ rRNA species. The sizes $(\mathrm{kb})$ of the transcripts determined by comparison of band mobilities with those of RNA markers are marked to the right of the autoradiograms.

\section{RESULTS}

\section{Restriction map of sk1}

In order to determine the transcript map for sk1 phage, it was necessary to construct a detailed restriction map of the phage to identify fragments which could be used as probes against Northern blots of phage mRNA. The sk1 restriction map for the enzymes EcoRI, EcoRV, HindIII, PvuII, Sau3AI and MspI, and an incomplete map for the enzyme $S s p I$, is shown in Fig. 1. The previously published EcoRV restriction map (Pillidge \& Jarvis, 1988; Powell et al., 1989; Chandry et al., 1994) has been modified 
(e)

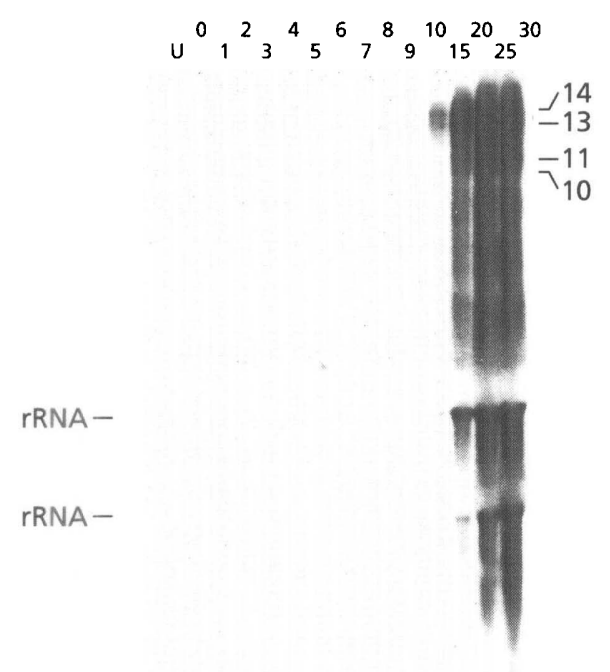

(f)

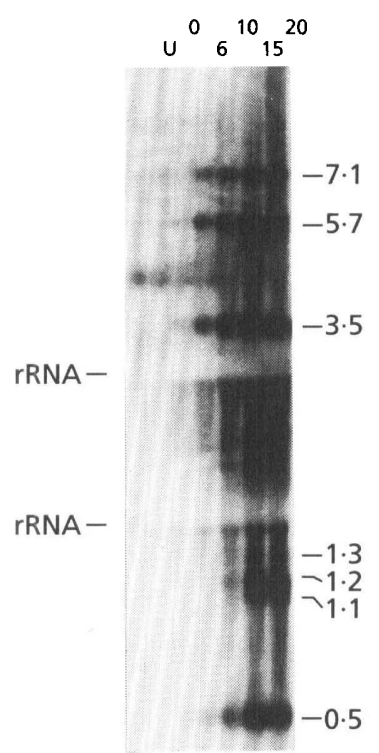

(g)

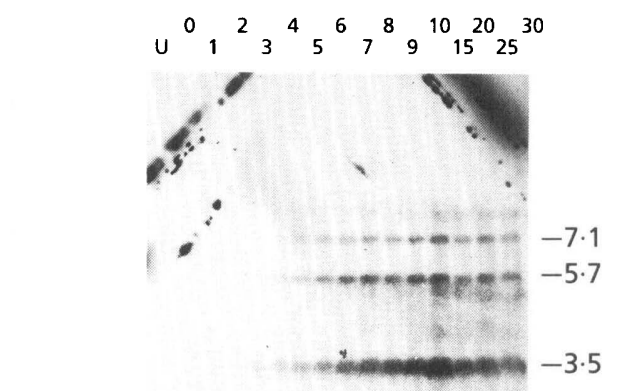

rRNA-

rRNAำ

to include a new fragment of $50 \mathrm{bp}, \mathrm{EvI}$, which was identified during nucleotide sequence analysis and confirmed by digestion and polyacrylamide gel electrophoresis (data not shown).

\section{Temporal regulation of phage transcripts}

RN A was isolated from $L$. lactis at various times after infection with sk1 phage, electrophoresed, and Northern blots of the gels were hybridized with DNA probes from different regions of the sk1 genome (Fig. 2). Tables 2-4 summarize the results of 55 hybridizations of 30 different Northern blots derived from 12 separate RNA preparations. Three temporal classes of phage specific transcripts, designated early, middle and late transcripts, were observed. The seven early phage transcripts (designated E1-E7 in order of decreasing size, Table 2) were first detected 2-5 min after phage infection (Fig. 2a and g, lanes 1-5). The intensity of hybridization to these transcripts decreased during the late stages of the infection (Fig. 2g). The nine middle phage transcripts (designated M1 M9 in order of decreasing size, Table 3) were first detected 7-10 min after infection (Fig. 2d, lanes 7-10) and the intensity of hybridization of DNA probes to these transcripts increased in later samples. Four late phage transcripts (designated L1-L4 in order of decreasing size, Table 4) were first detected approximately $15 \mathrm{~min}$ after infection (Fig. 2a, c and e, lanes 15-30) and thereafter the intensity of hybridization to these transcripts increased during the infection.

\section{Early stage transcripts}

The region of the phage genome from which the early phage transcripts were derived was determined by hybridizing specific phage fragments to the Northern blots. All probes that contained DNA from between $15.9 \mathrm{kbp}$ and $25.9 \mathrm{kbp}$ on the map (Fig. 1) hybridized to early transcripts, whereas probes containing DNA from outside this region did not (Table 2, Fig. 3). The early transcripts hybridizing to $\mathrm{SsC}$ are not visible in Fig. 2(e), but were visible in a longer exposure of the autoradiograph (data not shown) and are detected with the MsD probe (Fig. 2a), the right end of which is coincident with the right end of $\mathrm{SsC}$ (Fig. 1). The left-and right-hand limits to the region were established by $\mathrm{SaE}_{1}$ and $\mathrm{EvG}$, respectively, since neither of these fragments hybridized with any of the early phage transcripts. MsD hybridized to phage transcripts which appeared within 2-3 min of phage infection and also to phage transcripts which first appeared $15 \mathrm{~min}$ after infection (Fig. 2a and b). Hence, these fragments overlap the early and late regions of the phage. EvB hybridized to early and middle transcripts (Figs $2 \mathrm{f}$ and 3 ) and consequently overlaps the junction between the early and middle regions of the phage.

The evidence for the mapping of the seven early transcripts is as follows. The early transcripts E3, E4 and E6 hybridized with SsC, SsJ and SaG (Table 2, Fig. 3). However, none of these transcripts hybridized with $\mathrm{SsC}-$ 6 , which is deleted of the $400 \mathrm{bp}$ at the right end of $\mathrm{SsC}$ (Table 1, Fig. 3). Therefore, the left ends of E3, E4 and E6 must lie within this $400 \mathrm{bp}$ region. Of these three transcripts, only E6 hybridized with $\mathrm{SsC}-44$ (Table 2), which is deleted of $200 \mathrm{bp}$ from the right end of $\mathrm{SsC}$ (Table 1). This indicated that the left end of E6 extended into $\mathrm{SsC}_{\mathrm{S}}-44$, but not $\mathrm{SsC}_{\mathrm{s}}-6$, and mapped the left end of this transcript to approximately $15.9 \mathrm{kbp}$ on the sk1 map (Fig. 3). The right end was then mapped on the basis of transcript size to approximately $17.7 \mathrm{kbp}$ (Fig. 3). The right ends of E3 and E4 were also mapped on the basis of transcript size. It is possible that E3 and E4 also extend into $\mathrm{SsC}-44$ and share a common left end with E6, but 
Table 2. Hybridization of DNA probes to sk1 early transcripts

\begin{tabular}{|lccccccc|}
\hline \multirow{2}{*}{$\begin{array}{l}\text { DNA } \\
\text { probe* }\end{array}$} & \multicolumn{7}{c|}{ Transcript (kb): } \\
\cline { 2 - 7 } & E1 & E2 & E3 & E4t & E5† & E6 & E7 \\
& $\mathbf{( 7 \cdot 1 )}$ & $\mathbf{( 5 \cdot 7 )}$ & $\mathbf{( 3 \cdot 9 )}$ & $\mathbf{( 3 \cdot 5 )}$ & $\mathbf{( 3 \cdot 5 )}$ & $\mathbf{( 1 \cdot 8 )}$ & $\mathbf{( 0 \cdot 7 )}$ \\
\hline EvB & + & + & - & - & + & - & + \\
EvC & + & + & + & + & + & + & - \\
HiC & + & + & - & - & + & - & - \\
HiC-21 & + & + & - & - & - & - & - \\
HiC-24 & + & + & - & - & - & - & - \\
HiC-36 & + & - & - & - & - & - & - \\
HiD & + & - & - & - & - & - & + \\
MsD & - & - & + & + & - & + & - \\
Sa $\Delta$ A2 & + & + & - & - & + & - & - \\
Sa $\Delta$ A2-39 & + & + & - & - & + & - & - \\
SaG & - & - & + & + & - & + & - \\
SsC & - & - & + & + & - & + & - \\
SsC-6 & - & - & - & - & - & - & - \\
SsC-44 & - & - & - & - & - & + & - \\
Ss J & - & - & + & + & - & + & - \\
SsLNPR & - & - & - & - & - & - & + \\
SsLNPR-23 & - & - & - & - & - & - & + \\
SsLNPR-28 & - & - & - & - & - & - & + \\
SsLNPR-33 & - & - & - & - & - & - & + \\
SsNPR & - & - & - & - & - & - & + \\
SsNPR-10 & - & - & - & - & - & - & + \\
\hline
\end{tabular}

+ , DNA probe hybridized with sk1 transcript; - , no hybridization of DNA probe with sk1 transcript was detected.

* sk1 restriction fragment as described in Table 1 and Fig. 1.

t The assignment of probes hybridizing to E4 or E5 was inferred from the transcript map (Fig. 3).

were not detected by hybridization with $\mathrm{SsC}-44$ because of their comparatively low abundance (Fig. 2a) and small extent of overlap with the probe. The failure to observe hybridization of the $3.9 \mathrm{~kb}$ E3 transcript with either $\mathrm{SsC}$ 44 or $\mathrm{Sa} \Delta \mathrm{A} 2$, although these fragments are separated by only $3.5 \mathrm{kbp}$ (Fig. 3) is consistent with this suggestion. The left ends of the E3, E4 and E6 transcripts are therefore very similar (or identical) and these transcripts overlap each other (Fig. 3).

The early transcripts E1, E2 and E5 hybridized with $\mathrm{HiC}$ (Table 2), suggesting that these transcripts also overlap (Fig. 3). While E4 and E5 are the same size ( $3.5 \mathrm{~kb}), \mathrm{E} 5$ must be a different transcript to $\mathrm{E} 4$, which hybridized to $\mathrm{SaG}$, because $5.5 \mathrm{kbp}$ of DNA separates $\mathrm{HiC}$ from $\mathrm{SaG}$ (Fig. 1). The failure of $\mathrm{HiC}-24$ to hybridize with E5 (Table 2) enabled the right end of this transcript to be placed between map positions 22.0 and $22.5 \mathrm{kbp}$ (Fig. 3). Similarly, because E2 hybridized to $\mathrm{HiC}-21$, but not to HiC-36 (Table 2), its right end was located between map positions 23.7 to $23.9 \mathrm{kbp}$ (Fig. 3). Similarly, E1 hybridized to SsLNPR and HiD but not to SsNPR (Table 2 ) and therefore its right end was placed between 24.6 and
$25 \mathrm{kbp}$ (Fig. 3). The left ends of E1, E2 and E5 were then deduced from the size of these transcripts.

The early transcript E7 hybridized with SsNPR and SsLNPR and their subfragments SsNPR-10 and SsLNPR28 (Table 2). These data indicated that most of this transcript was from within SsNPR, with a right end close to the $25.9 \mathrm{kbp}$ position on the map (Fig. 3).

\section{Orientation of the early phage transcripts}

The direction of transcription of the early phage genes encoding E1, E2 and E5 was determined by using probes consisting of single-stranded DNA covering the phage $\mathrm{Sa} \Delta \mathrm{A} 2$ fragment (Fig. 1). These probes from either end of the cloned fragment were prepared as described in Methods and hybridized to Northern blots of RNA isolated from sk1-infected cells. Only the probe with the $5^{\prime}$ end oriented to the left of the maps shown in Figs 1 and 3 hybridized to the phage RNA (data not shown), indicating that E1, E2 and E5 are oriented in the right to left direction of the maps shown in Figs 1 and 3 . Nucleotide sequence data subsequently showed that the open reading frames encoded by the early phage genes were all oriented in the right to left direction, thus confirming the hybridization data (data not shown).

\section{Determination of the $5^{\prime}$ end of early transcripts by primer extension analysis}

Primer extension analyses (Fig. $4 \mathrm{a}$ and data not shown) were used to map precisely the $5^{\prime}$ ends of E1 and E5 to map positions $25 \mathrm{kbp}$ and $22.7 \mathrm{kbp}$ respectively (Fig. 3). In both cases two $5^{\prime}$ ends of the transcripts were detected (Fig. $4 \mathrm{a}, \mathrm{b}$ and d). Putative promoter sequences which showed homology with other lactococcal promoters (van de Guchte et al., 1992) were present in the DNA upstream of the $5^{\prime}$ end of both transcripts (Fig. $4 \mathrm{~b}$ and d). Primer extension experiments also detected the $5^{\prime}$ end of a transcript within $\mathrm{Sa} \Delta \mathrm{A} 2$ approximately $200 \mathrm{bp}$ from its left end at $19.9 \mathrm{kbp}$ on the sk1 map (Fig. 3). This $5^{\prime}$ end was located within an open reading frame and was not preceded by a recognizable promoter sequence (Fig. 4c). It may be the $5^{\prime}$ end of E3, although as discussed above, no hybridization of this transcript with the $\mathrm{Sa} \Delta \mathrm{A} 2$ probe was detected (Fig. 2g, Table 2). Identification of the $5^{\prime}$ ends of other early phage transcripts was prevented by the instability of molecular clones containing appropriate regions of the phage DNA and a lack of nucleotide sequence data.

\section{Middle phage transcripts}

The three middle transcripts M1, M2 and M3 hybridized with EvF and EvG (Fig. 2d, Table 3) and were first detected 7-10 min after infection. In addition, a number of smaller transcripts (M4-M9) ranging in size from $0.2 \mathrm{~kb}$ to $0.9 \mathrm{~kb}$ were observed to hybridize with EvF at later time points. As these transcripts did not hybridize to SsINPR or EvD, they must have been transcribed from 


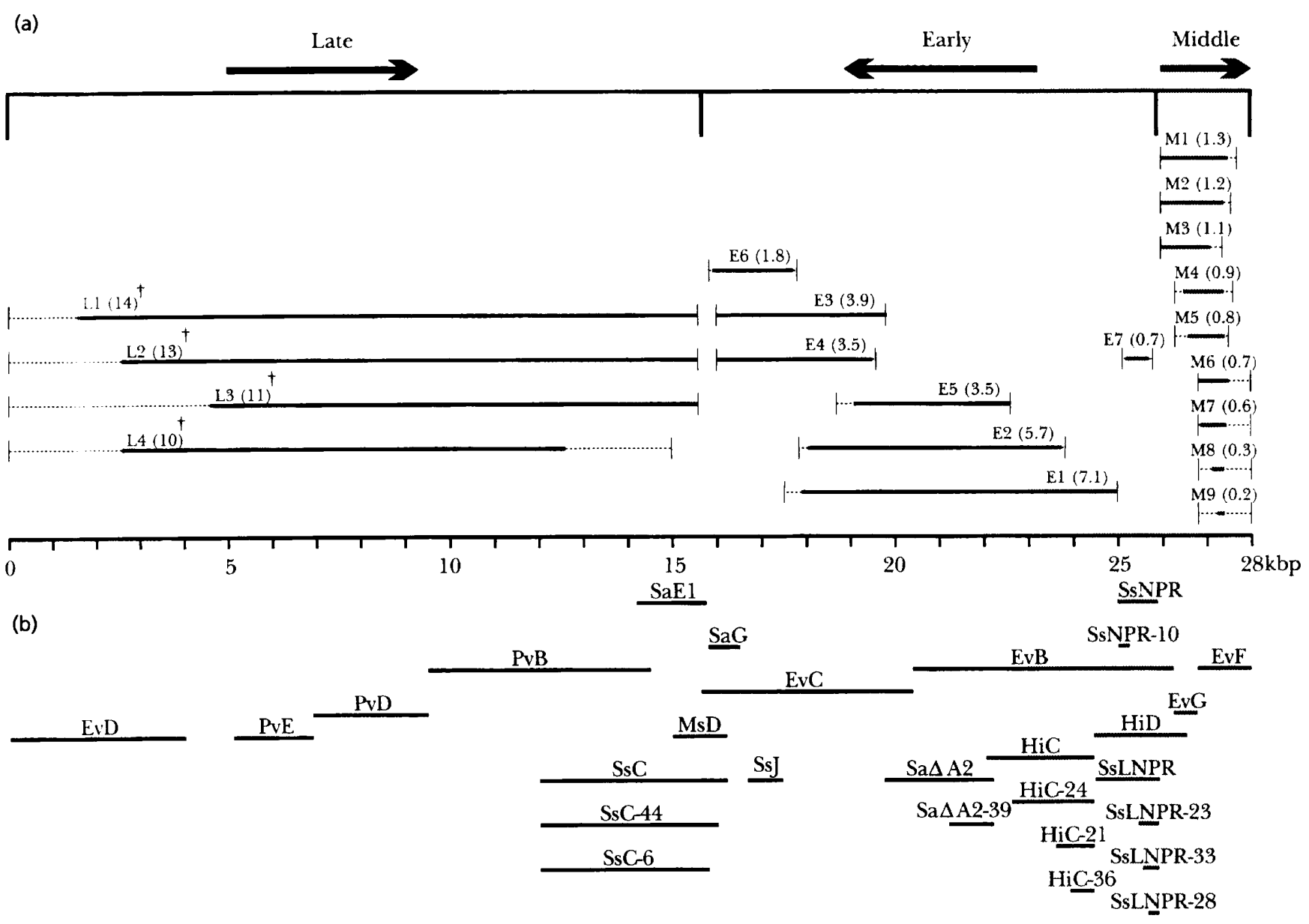

Fig. 3. Transcript map of phage sk1. The position and length of phage transcripts (a) and DNA probes (b) used to construct the map are shown relative to a scale showing the size of the sk1 physical map. Arrows indicate the directions of transcription of the phage genome based on hybridization and sequence data. Grouping of the transcripts into early $(E)$, middle (M), and late $(L)$ is based on the time of appearance of transcripts as described in the text. Transcripts are represented by solid lines and labelled E1, E2, etc., in order of decreasing size. The numbers in parentheses indicate the predicted length of the transcripts in $\mathrm{kb}$. Uncertainties in the location of the ends of transcripts are indicated by broken lines. Transcripts marked with $(t)$ migrated more slowly than the biggest molecular size marker and their sizes were obtained by extrapolation of the standard curve. The location and length of the hybridization probes are shown as thick lines beneath the name of the DNA probe. DNA probes are named according to the nomenclature described in the legend to Fig. 1 and are defined in Table 1.

DNA mapping between $25.8 \mathrm{kbp}$ and $28.0 \mathrm{kbp}$ on the sk 1 map (Fig. 3). In view of the size and number of the middle transcripts and the small region of the genome from which they are derived, at least some of these transcripts must overlap. Nucleotide sequence data showed that the open reading frames encoded by the middle genes of the phage were all oriented in the left to right direction on the physical map shown in Fig. 1 (data not shown). Thus it was concluded that the early and middle phage genes are transcribed in opposite directions from a region located at approximately $26 \mathrm{kbp}$ on the sk $1 \mathrm{map}$. The middle transcripts did not appear to span the sk1 cos region, as EvD did not hybridize to any transcripts until $15 \mathrm{~min}$ post-infection (Fig. 2c). A weakly hybridizing smear of large late transcripts was detected with the EvF probe (Table 4), indicating that a small amount of transcription initiating from a promoter within EvF may proceed across cos into the late region of the genome in the final stages of phage infection.

\section{Late phage transcripts}

Various DNA probes located between $0 \mathrm{kbp}$ and $16 \mathrm{kbp}$ on the physical map shown in Fig. 1 hybridized to phage transcripts which were not detected until approximately 15 min after infection (Figs 2a, b, c and e, Table 4). Because the discrete bands of these transcripts migrated more slowly than the biggest available size marker $(9 \cdot 5 \mathrm{~kb})$, their sizes were determined by extrapolation of the standard curve and are therefore only indicative values. Some probes hybridized to discrete transcripts of 14, 13, 11 and $10 \mathrm{~kb}$ (Table 4, Fig. 2b and e). However, in contrast to the Northern blots of the early and middle transcripts, where the phage transcripts yielded sharp 


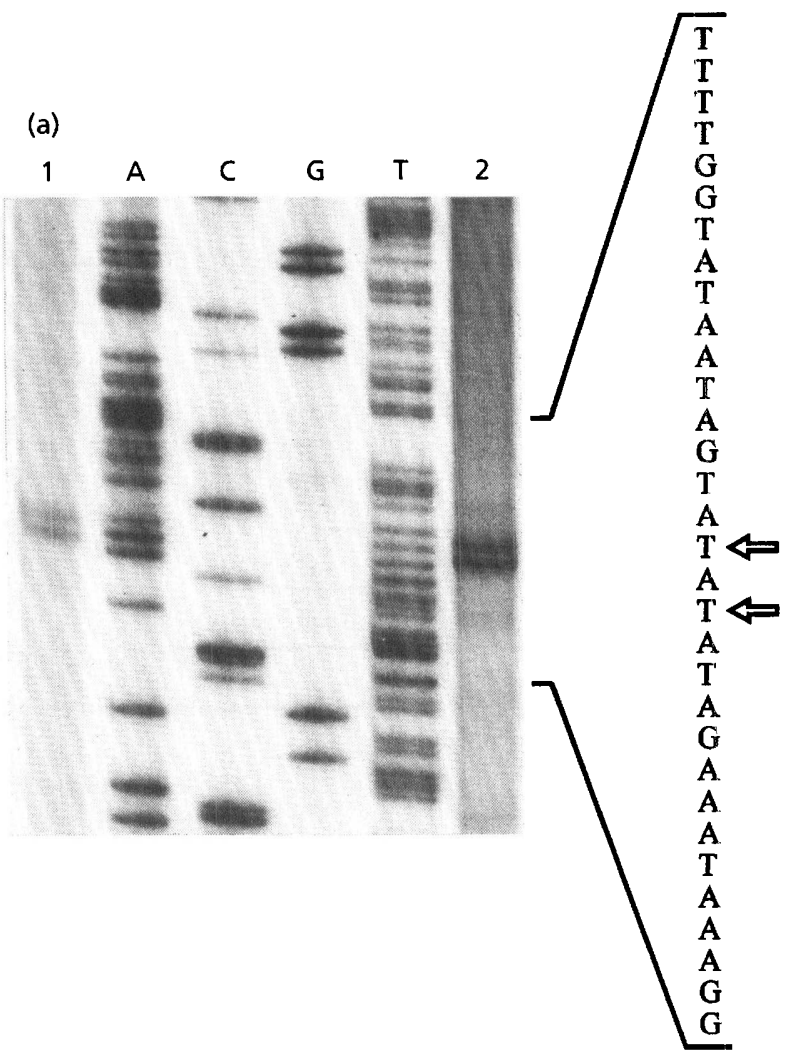

Fig. 4. Primer extension analysis of the 5 end of sk1 early transcripts. (a) Autoradiograph showing electrophoretic separation of a sequencing ladder and the products of primer extension from a 17-mer oligonucleotide complementary to a portion of E5 annealed to RNA isolated from L. lactis 10 min after infection with sk1 phage. Lanes 1 and 2 contain 3 and $8 \mu l$ respectively of primer extension reaction mixture. Lanes $A$, $C, G$ and $T$ contain the relevant nucleotide sequencing reactions which utilized cloned sk1 HiC fragment as template and the oligonucleotide used for primer extension as primer. The nucleotide sequence on the right margin is that of the sense strand of the DNA and reads from right to left of the transcript map shown in Fig. 3. (b), (c) and (d) Nucleotide sequences surrounding the $5^{\prime}$ ends of transcripts E1, E3 and E5 respectively. The $5^{\prime}$ ends of the transcripts as determined by primer extension are indicated with arrowheads. Nucleotide sequences which show homology with -10 and -35 regions of promoters from Grampositive and Gram-negative organisms are underlined. The $5^{\prime}$ ends of E1 (b) and E5 (d) are located within intergenic regions of the phage DNA, while the $5^{\prime}$ end of E3 (c) is located within an open reading frame, the deduced amino acid sequence of which is shown beneath the nucleotide sequence.

(b)

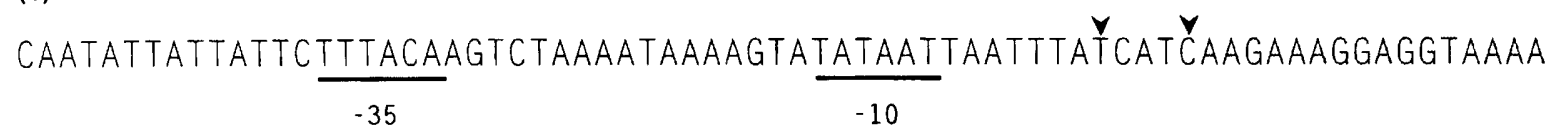

(c)

GTAAACTATAACTTTGTTTTCCCTACGGTTGAAAAAGTATTTATCACTAA $\stackrel{\square}{T}$ GATAATAGTAGTCAATCACA

$V N Y N$ F V F P T V E K V F I T N D N

(d)

AAAATATCATCTAATATTTGACAACGATAATTAATTTTGGTATAATAGTA

$-35$

$-10$

bands, probes such as EvD hybridized to a smear of phage transcripts ranging in size from about 300 bases to greater than $10 \mathrm{~kb}$ (Fig. 2c). This smearing may have resulted from non-specific processing of phage transcripts, transcript degradation, the presence of transcripts of increasing size with a common $5^{\prime}$ end located within EvD, or a combination of these factors.

The right ends of the L1, L2 and L3 were placed at (approximately) $15.7 \mathrm{kbp}$ on the sk1 map because the transcripts hybridized with $\mathrm{MsD}$ but not EvC (Fig. 3, Table 4). Their left ends were located by transcript size and, for L1 and L2, confirmed by hybridization with EvD. Unlike the other late transcripts, L4 did not hybridize with MsD although it did with SsC (Fig. 2b and e). It is therefore likely that the $3^{\prime}$ end of this transcript is located to the left of the $3^{\prime}$ ends of the other three late phage transcripts. Its $5^{\prime}$ end may therefore coincide with that of the $11 \mathrm{~kb}$ transcript (Fig. 3). Nucleotide sequence data showed that the open reading frames in the sk1 late 
Table 3. Hybridization of DNA probes to sk1 middle transcripts

\begin{tabular}{|c|c|c|c|c|c|c|c|c|c|}
\hline \multirow{2}{*}{$\begin{array}{l}\text { DNA } \\
\text { probe }\end{array}$} & \multicolumn{9}{|c|}{ Transcript (kb): } \\
\hline & $\begin{array}{c}\text { M1 } \\
(1 \cdot 3)\end{array}$ & $\begin{array}{c}\text { M2 } \\
(1 \cdot 2)\end{array}$ & $\begin{array}{c}\text { M3 } \\
(1 \cdot 1)\end{array}$ & $\begin{array}{c}\text { M4 } \\
(0.9)\end{array}$ & $\begin{array}{c}\text { M5 } \\
(0 \cdot 8)\end{array}$ & $\begin{array}{c}\text { M6 } \\
(0 \cdot 7)\end{array}$ & $\begin{array}{c}\text { M7 } \\
(0 \cdot 6)\end{array}$ & $\begin{array}{c}\text { M8 } \\
(0 \cdot 3)\end{array}$ & $\begin{array}{c}\text { M9 } \\
(0.2)\end{array}$ \\
\hline EvB & + & + & + & - & - & - & - & - & - \\
\hline EvF & + & + & + & + & + & + & + & + & + \\
\hline EvG & + & + & + & + & + & - & - & - & - \\
\hline $\mathrm{HiD}$ & + & + & + & + & + & - & - & - & - \\
\hline
\end{tabular}

+ , DN $A$ probe hybridized with sk 1 transcript; - , no hybridization of DNA probe with sk1 transcript was detected.

Table 4. Hybridization of DNA probes to sk1 late transcripts

\begin{tabular}{|c|c|c|c|c|}
\hline \multirow{2}{*}{$\begin{array}{l}\text { DNA } \\
\text { probe }\end{array}$} & \multicolumn{4}{|c|}{ Transcript (kb): } \\
\hline & $\begin{array}{c}\text { L1 } \\
(14)\end{array}$ & $\begin{array}{c}\text { L2 } \\
\text { (13) }\end{array}$ & $\begin{array}{c}\text { L3 } \\
\text { (11) }\end{array}$ & $\begin{array}{c}\text { L4 } \\
\text { (10) }\end{array}$ \\
\hline I.vD & + & + & $\mathrm{sm}$ & $\mathrm{sm}$ \\
\hline $\mathrm{EvF}$ & \pm & \pm & - & - \\
\hline $\mathrm{MsD}$ & + & + & + & - \\
\hline$P \vee B$ & + & $\mathrm{sm}$ & $\mathrm{sm}$ & $\mathrm{sm}$ \\
\hline PvD & + & $\mathrm{sm}$ & $\mathrm{sm}$ & $\mathrm{sm}$ \\
\hline PvE & + & $\mathrm{sm}$ & $\mathrm{sm}$ & $\mathrm{sm}$ \\
\hline $\mathrm{SaE} 1$ & + & $\mathrm{sm}$ & $\mathrm{sm}$ & $\mathrm{sm}$ \\
\hline $\mathrm{SsC}$ & + & + & + & + \\
\hline $5 s \mathrm{C}-6$ & + & + & + & + \\
\hline Ssc- 44 & + & + & + & + \\
\hline
\end{tabular}

+ , DNA probe hybridized with sk1 transcript; sm, the hybridization pattern was smeared, preventing the detection of individual bands; \pm , the hybridization to these transcripts was very weak; - , no hybridization of DNA probe with sk1 transcript was detected.

region were all oriented in the left to right direction of the map shown in Fig. 1 (data not shown).

In addition to the late transcripts derived from the $0-16 \mathrm{kbp}$ region of the phage genome, a late $2 \cdot 2 \mathrm{~kb}$ RNA species, migrating between the $16 \mathrm{~S}$ and $23 \mathrm{~S}$ rRNA bands, was detected in some RNA preparations (Fig. 2d and g). When present, this RNA species hybridized to EcoRV fragments $B, C, F$ and $G$ and therefore is not a single RNA species and may be breakdown products of early and middle transcripts.

\section{DISCUSSION}

The propagation of bacteriophages containing a doublestranded DNA genome generally involves two or three time-dependent phases of phage gene expression. These phases of phage gene expression are usually controlled at the level of transcription and result in a complex, often overlapping, time-dependent pattern of phage transcripts. For example, transcription of the Escherichia coli phage T7 is essentially unidirectional along the linear genome, but a complex pattern of transcripts is observed due to the initiation of transcription at several points, the processing of long transcripts and partial readthrough of transcription termination sites (Dunn \& Studier, 1983). T7 transcription is also regulated temporally by the synthesis of a T7-encoded RNA polymerase which recognizes T7 middle and late promoters. The work described in this paper has shown that the small isometric-headed lactococcal phage sk1 exhibits a complex pattern of transcription which is temporally regulated into three distinct phases cortesponding to early, middle and late stages of infection.

By analogy with other bacteriophages, it is likely that the sk1 early transcripts are initiated from promoters recognized by the (unmodified) host RNA polymerase. Seven early sk1 transcripts were detected $2-5 \mathrm{~min}$ after phage infection and were derived from a $10 \mathrm{kbp}$ region of the phage genome located between 15.9 and $25.9 \mathrm{kbp}$ on the sk1 map (Fig. 3). These transcripts were oriented in the right to left direction on the sk1 map and ranged in size from 0.7 to $7 \cdot 1 \mathrm{~kb}$. Three of the transcripts (E1, E6 and E7) do not overlap and cover the entire $10 \mathrm{kbp}$ of the early region of the genome, while the other four transcripts (E2-E5) overlap regions of the genome covered by E1 and E6.

The $5^{\prime}$ ends of E1 and E5 were determined by primer extension studies to be located in intergenic regions between open reading frames and each was preceded by nucleotide sequences similar to consensus lactococcal and E. coli promoters (Harley \& Reynolds, 1987; van de Guchte et al., 1992). While promoter cloning experiments are required to prove the functionality of these putative promoters and eliminate the possibility that E1 and/or E5 arose by processing of a larger transcript, these data suggest that sk1 phage contains at least two early promoters. At least one additional early promoter would be necessary to initiate transcription of E7. The $5^{\prime}$ end of another transcript, which mapped to approximately $200 \mathrm{bp}$ from the left end of $\mathrm{S} a \mathrm{~A} 2$, may be that of $\mathrm{E} 3$. Because this end lies within an open reading frame and was not preceded by a recognizable lactococcal promoter sequence, it is likely that this transcript was derived by processing of a larger transcript. Interestingly, early transcripts larger than $7 \cdot 1 \mathrm{~kb}$ can be weakly detected in hybridizations with $\mathrm{Sa} \Delta \mathrm{A} 2$ (Fig. $2 \mathrm{~g}$ ) and other probes from the early region (data not shown) and may represent unprocessed transcripts. These data suggest that the early sk1 transcripts identified in this study include primary transcripts, initiated from at least three early promoters, and processed products of (some of) these primary transcripts. The presence of processed and overlapping transcripts has been observed in lytic phage that infect E. coli and Bacillus subtilis (Christensen \& Young, 1983; Panganiban \& Whiteley, 1983a, b; Dunn \& Studier, 1983). Their synthesis may be a mechanism to achieve differential levels of gene expression from a limited number of promoters. 
The precise locations of the $3^{\prime}$ ends of the early transcripts have not been determined. However, E3, E4 and E6 terminated within a $400 \mathrm{bp}$ region within $\mathrm{SsC}$ and may share a common termination point. In agreement with the results obtained in this investigation, Beresford et al. (1993), using phage cDNA probes, also determined that the sk 1 early transcripts were derived from a region of the phage genome corresponding to EvB, EvC and EvG.

By analogy with other lytic bacteriophages, it is likely that middle and late transcripts are initiated from promoters that are not recognized by the host RNA polymerase and that transcription from these promoters is dependent on phage-encoded proteins produced in previous phases of the phage replication cycle. The nine middle sk 1 phage transcripts were first detected $7-10 \mathrm{~min}$ after phage infection and were derived from a $2 \cdot 1 \mathrm{kbp}$ region of the phage genome between $26 \mathrm{kbp}$ and the phage cos site at $28 \mathrm{kbp}$ on the map of sk1 (Fig. 3). These transcripts ranged in size from 0.2 to $1.3 \mathrm{~kb}$ and were oriented in the opposite direction to the early transcripts. While the precise ends of the middle transcripts were not determined, it is obvious that the transcription pattern in this region is quite complex and that many of the transcripts overlap. Either there are multiple transcription initiation and termination sites within this region, or most of the middle transcripts are likely to be processed products of larger middle transcripts. In contrast to the results of Beresford et al. (1993), no evidence that the middle transcripts traversed cos and were derived from the EvD region of the phage was obtained in this investigation (Figs $2 \mathrm{c}$ and 3 ). However, weak hybridization of EvF with large late transcripts was observed $15 \mathrm{~min}$ after phage infection, indicating that some late transcripts may initiate from the same region as the middle transcripts and traverse cos. These transcripts could be initiated from a late promoter within the middle region of the phage genome or by antitermination of transcripts initiated from a middle promoter.

The four late phage transcripts were not detected until 15 min after phage infection and were derived from a $16 \mathrm{kbp}$ region of the phage genome between 0 and $16 \mathrm{kbp}$ on the sk1 map (Fig. 3). Like the middle transcripts, they were oriented in the opposite direction to the early transcripts. Three of the late transcripts (L1, L2 and L3) and three of the early transcripts (E3, E4 and E6) terminated within the $1 \cdot 2 \mathrm{kbp}$ of DNA spanned by $\mathrm{MsD}$, suggesting that there may be a common region of transcription termination for these convergent early and late transcripts. A region containing back-to-back terminators capable of terminating convergent transcription has recently been identified in the L. lactis chromosome (Llanos et al., 1992). The mapping of the end-points of the late transcripts was less precise than that of the early and middle transcripts because of the large transcript sizes and the smeared appearance of Northern blots hybridized with probes from the late region. The smeared hybridization pattern could result from the presence of a series of nascent late transcripts of increasing size initiating from a common initiation site, or from the rapid processing or degradation of full--length transcripts. It is also possible that there are a number of transcription initiation and termination sites within the late region and that these contribute to the range of transcript sizes observed.

As observed with the early and middle transcripts, the late phage transcripts also overlap each other. Given the uncertainty in the size of the large late transcripts, it is possible that the $5^{\prime}$ end of L1 is close to cos and that this transcript therefore spans the entire late region. If the lactococcal (or phage encoded) RNA polymerase synthesizes RNA at a similar rate to the $E$. coli enzyme (Bremer \& Yuan, 1968), it would take approximately $5 \mathrm{~min}$ to synthesize a $16 \mathrm{~kb}$ transcript. This may provide an additional level of temporal regulation of phage gene expression. However, as the $3^{\prime}$ end of L 1 is common to L 2 and L3, which are approximately 13 and $11 \mathrm{~kb}$ in length, the delay in translation of proteins from the distal ends of these transcripts would be less than 5 min. Further work will study the regulation of gene expression and mechanisms of mRNA processing in this phage.

\section{ACKNOWLEDGEMENTS}

We are grateful to Sean Moore for technical assistance, John Boyce for helpful discussions, Clinton Grant for synthesizing oligonucleotides and Phil Arnold and Ian Powell for assistance with the restriction mapping.

\section{REFERENCES}

Beresford, T. P. J., Ward, L. J. H. \& Jarvis, A. W. (1993). Temporally regulated transcriptional expression of the genomes of lactococcal bacteriophages c2 and sk1. Appl Environ Microbiol 59, 3708-3712.

Bremer, H. \& Yuan, D. (1968). RNA chain growth rates in Escherichia coli. J Mol Biol 38, 163-180.

Chandry, P. S., Moore, S. C., Davidson, B. E. \& Hillier, A. J. (1994). Analysis of the cos region of the Lactococcus lactis bacteriophage sk1. Gene 138, 123-126.

Chen, J. \& Morrison, D. A. (1988). Construction and properties of a new insertion vector, pJDC9, that is protected by transcriptional terminators and useful for cloning of DNA from Streptococcus pneumoniae. Gene 64, 155-164.

Christensen, A. C. \& Young, E. T. (1983). Characterization of T4 transcripts. In Bacteriophage T4, pp. 184-188. Edited by C. K. Mathews, E. M. Kutter, G. Mosig \& P. B. Berget. Washington, DC: American Society for Microbiology,

Chung, D. K., Kim, J. H. \& Batt, C. A. (1991). Cloning and nucleotide sequence of the major capsid protein from Lactococcus lactis ssp. cremoris bacteriophage F4-1. Gene 101, 121-125.

Dunn, J. J. \& Studier, F. W. (1983). Complete nucleotide sequence of bacteriophage T7 DNA and the locations of $T 7$ genetic elements. J Mol Biol 166, 477.535.

Feinberg, A. P. \& Vogelstein, B. (1984). A technique for radiolabeling DNA restriction fragments to high specific activity. Anal Biochem 137, 266-267.

van de Guchte, M., Kok, J. \& Venema, G. (1992). Gene expression in Lactococcus lactis. FEMS Microbiol Rev 88, 73-92.

Harley, C. B. \& Reynolds, R. P. (1987). Analysis of E. coli promoter sequences. Nucleic Acids Res 15, 2343-2361.

Hill, C., Miller, L. A. \& Klaenhammer, T. R. (1991). In vivo genetic exchange of a functional domain from a type II A methylase between lactococcal plasmid pTR2030 and a virulent bacteriophage. $J$ Bacteriol 173, 4363-4370. 
Jarvis, A. W., Fitzgerald, G. F., Mata, M., Mercenier, A., Neve, H., Powell, I. B., Ronda, C. \& Saxelin, M. T. (1991). Species and type phazes of lactococcal bacteriophages. Intervirology 32, 2-9.

Kim, J. H. \& Batt, C. A. (1991). Nucleotide sequence and deletion analysis of a gene coding for a structural protein of Lactococcus lactis bacteriophage F4-1. Food Microbiol 8, 27-36.

Klaenhammer, T. R. (1987). Plasmid-directed mechanisms for bacteriophage defense in lactic streptococci. FEMS Microbiol Rev $46,313-325$

Lakshmidevi, G., Davidson, B. E. \& Hillier, A. J. (1991). Molecular characterization of promoters of the Lactococcus lactis subsp. cremoris temperate bacteriophage BK5- $T$ and identification of a phage gene implicated in the regulation of promoter activity. Appl Environ Microbiol 56, 934-942.

Lillehaug, D. \& Birkeland, N. (1993). Characterization of genetic elements required for site-specific integration of the temperate lactococcal bacteriophage $\phi \mathrm{LC} 3$ and construction of integrationnegative $\phi \mathrm{LC} 3$ mutants. J Bacteriol 175, 1745-1755.

Llanos, R. M., Hillier, A. J. \& Davidson, B. E. (1992). Cloning, nucleotide sequence, expression, and chromosomal location of $l d h$, the gene encoding $\mathrm{L}-(+)$-lactate dehydrogenase, from Lactococcus lactis. I Bacteriol 174, 6956-6964.

Maniatis, T., Fritsch, E. F. \& Sambrook, J. (1982). Molecular Cloning: a Laboratory Manual. Cold Spring Harbor, NY : Cold Spring Harbor Laboratory.

O'Sullivan, D. J., Hill, C. \& Klaenhammer, T. R. (1993). Effect of increasing the copy number of bacteriophage origins of replication, in trims, on incoming-phage proliferation. Appl Environ Microbiol 59, 2449-2456.

Panganiban, A. T. \& Whiteley, H. R. (1983a). Purification and properties of a new Bacillus subtilis RNA processing enzyme. $J$ Biol Chem: 258, 12487-12493.

Panganiban, A.T. \& Whiteley, H. R. (1983b). Bacillus subtilis RNAase III cleavage sites in phage SP82 early mRNA. Cell 33, 907-913.
Pillidge, C. J. \& Jarvis, A. W. (1988). DNA restriction maps and classification of the lactococcal bacteriophages $\mathrm{c} 2$ and sk1. $\mathrm{NZJ}$ Dairy Sci Technol 23, 411-416.

Platteeuw, C. \& de Vos, W. M. (1992). Location, characterization and expression of lytic enzyme-encoding gene, lyt A, of Lactococcus lactis bacteriophage $\phi \mathrm{US} 3$. Gene 118, 115-120.

van Rooijen, R. J. \& de Vos, W. M. (1990). Molecular cloning, transcriptional analysis, and nucleotide sequence of $l a c R$, a gene encoding the repressor of the lactose phosphotransferase system of Lactococcus lactis. I Biol Chem 265, 18499-18503.

Powell, I. B., Arnold, P. M., Hillier, A. J. \& Davidson, B. E. (1989). Molecular comparison of prolate- and isometric-headed bacteriophages of lactococci. Can J Microbiol 35, 860-866.

Powell, I. B., Ward, A. C., Hillier, A. J. \& Davidson, B. E. (1990). Simultaneous conjugal transfer in Lactococcus of genes involved in bacteriocin production and reduced susceptibility to bacteriophages. FEMS Microbiol Lett 72, 209-214.

Shearman, C., Underwood, H., Jury, K. \& Gasson, M. (1989). Cloning and DNA sequence analysis of a Lactococcus bacteriophage lysin gene. Mol \& Gen Genet 218, 214-221.

Terzaghi, B. E. (1976). Morphologies and host sensitivities of lactic streptococcal phages from cheese factories. $N Z$ J Dairy $S_{c i}$ Technol 11, 155-163.

Terzaghi, B. E. \& Sandine, W. E. (1975). Improved medium for lactic streptococci and their bacteriophages. Appl Microbiol 29, 807-813.

Ward, A. C., Davidson, B. E., Hillier, A. J. \& Powell, I. B. (1992). Conjugally transferable phage resistance activities from Lactococcus lactis DRC1. J Dairy Sci 75, 683-691.

Ward, L. J. H., Beresford, T. P. J., Jarvis, B. D. W. \& Jarvis, A. W. (1993). Sequence analysis of the lysin gene region of the prolate lactococcal bacteriophage c2. Can J Microbiol 39, 767-774.

Received 4 January 1994; revised 10 May 1994; accepted 20 May 1994. 